Journal of Telenursing (JOTING)

Volume 1, Nomor 1, Juni 2019

e-ISSN : 2684-8988

p-ISSN : 2684-8996

DOI: https://doi.org/10.31539/joting.v1i1.539

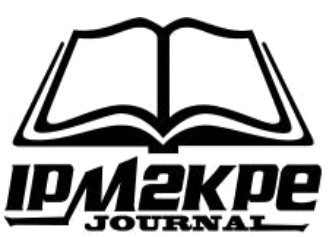

\title{
PERBANDINGAN SLOW DEEP BREATHING DENGAN KOMBINASI BACK MASSAGE DAN SLOW DEEP BREATHING TERHADAP TEKANAN DARAH
}

\author{
Ramadhan Trybahari ${ }^{1}$, Busjra ${ }^{2}$, Rohman Azzam ${ }^{3}$ \\ Politeknik Kesehatan Kementerian Kesehatan Jayapura ${ }^{1}$ \\ Universitas Muhammadiyah Jakarta ${ }^{2,3}$ \\ Adhanfirady@gmail.com ${ }^{1}$
}

\begin{abstract}
ABSTRAK
Penelitian ini bertujuan untuk mengetahui pengaruh terapi kombinasi back massage dan slow deep breathing terhadap perubahan tekanan darah pada pasien hipertensi. Studi kuantitatif non equivalent control group pretest - posttest design. Hasil penelitian menunjukkan adanya perbedaan yang bermakna pada tekanan darah antara kelompok intervensi kombinasi BM dan SDB dengan kelompok SDB $(\mathrm{p}=0,000 ; \alpha=0,05)$ terhadap tekanan darah sistolik dan diastolik pada hari kelima. Simpulan, teknik kombinasi BM dan SDB merupakan usaha yang efektif terhadap perubahan tekanan darah.
\end{abstract}

Kata Kunci : Back Massage, Hipertensi, Slow Deep Breathing

\section{ABSTRACT}

This study aims to determine the effect of combination therapy back massage and slow deep breathing on changes in blood pressure in hypertensive patients. Quantitative study non equivalent control group pretest - posttest design. The results showed that there was a significant difference in blood pressure between the combined intervention group BM and $S D B$ and $S D B$ group $(p=0.000 ; \alpha=0.05)$ on systolic and diastolic blood pressure on the fifth day. In conclusion, the combination technique of BM and $S D B$ is an effective attempt to change blood pressure.

Keywords: Back Massage, Hypertension, Slow Deep Breathing

\section{PENDAHULUAN}

Hipertensi atau tekanan darah tinggi adalah kondisi kronis di mana tekanan darah pada dinding arteri meningkat. Hipertensi merupakan peningkatan tekanan darah sistolik lebih dari $140 \mathrm{mmHg}$ dan tekanan darah diastolik lebih dari $90 \mathrm{mmHg}$ pada dua kali pengukuran dengan selang waktu selama lima menit dalam keadaan cukup istirahat/tenang. Hipertensi menempatkan jantung dan arteri dibawah ketegangan abnormal. Tekanan berlebihan secara bertahap menimpa organ tubuh yang mendapat nutrisi dari pasokan darah. Hasilnya pembuluh darah diotak bisa pecah dan menyebabkan stroke. Atau kemampuan ginjal untuk menyaring sampah terganggu. Jantung yang harus bekerja dengan lebih keras untuk memompakan darah agar mengimbangi peningkatan tekanan dalam arteri, mulai menegang. 
World Health Organization (WHO) mencatat pada tahun 2013 sedikitnya terdapat 972 juta kasus hipertensi dan diperkirakan akan menjadi 1,15 milyar kasus tahun 2025 atau sekitar $29 \%$ total penduduk di dunia menderita hipertensi, dimana 333 juta dinegara maju dan 639 juta sisanya dinegara berkembang termasuk di Indonesia. Dari angka tersebut dapat dinyatakan bahwa ditahun 2025 satu dari tiga orang dewasa diseluruh dunia menderita hipertensi (WHO, 2013). Jumlah penderita hipertensi setiap tahun di seluruh dunia terus meningkat. Pada tahun 2012 Cardiovascular Disease (CVD) membunuh 17,5 juta orang setara dengan setiap 3 dari 10 kematian, dari 17 juta kematian ini dalam setahun lebih dari 9,4 juta disebabkan oleh komplikasi pada hipertensi yang juga sering disebut peningkatan tekanan darah tinggi (IFPMA, 2016). Kawasan Asia Tenggara termasuk Indonesia, dilaporkan bahwa 49,7\% penyebab kematian adalah akibat penyakit tidak menular, salah satu di antaranya adalah hipertensi (Irawan, 2017; Sartika et al., 2018).

Pada astudi pendahuluan di Puskesmas Nabire Kota Kabupaten Nabire didapatkan jumlah pasien hipertensi yang berkunjung pada 2016 sebanyak 764 pasien dan meningkat pada tahun 2017 sebanyak 902 pasien dan terhitung setiap bulannya rata-rata mencapai 75 pasien yang datang ke Puskesmas Nabire Kota Kabupaten Nabire.

Salah satu penyebab tingginya prevalensi hipertensi yaitu tingkat stres individu yang semakin tinggi akibat globalisasi yang menuntut persaingan di segala bidang. Stres dapat meningkatkan resistensi vaskular perifer dan curah jantung, serta merangsang aktifitas sistim saraf simpatis sehingga tekanan darah meningkat. Dalam mengatasi peningkatan tekanan darah disinilah peran perawat dibutuhkan dengan menerapkan berbagai terapi non farmakologis, yaitu dengan melakukan manajemen stres, diantaranya adalah teknik relaksasi yang merupakan tindakan mandiri perawat yang cukup praktis dan dapat diimplementasikan sendiri oleh keluarga pasien atau dilakukan oleh pasien secara mandiri. sehingga diharapkan dapat menurunkan dosis obat antihipertensi yang dikonsumsi (Majid, 2017).

Relaksasi efektif menurunkan denyut jantung dan tekanan darah, menurunkan ketegangan otot, meningkatkan kesejahteraan, dan mengurangi tekanan gejala pada individu yang mengalami berbagai situasi. Teknik relaksasi banyak jenisnya, diantaranya teknik back massage merupakan teknik relaksasi dengan pijatan lembut pada jaringan yang bertujuan yang memberikan efek terhadap fisiologis terutama pada vaskular, muskular, dan sistem saraf pada tubuh. Teknik relaksasi pernapasan slow deep breathing yaitu tindakan yang disadari untuk mengatur pernapasan secara dalam dan lambat. Back massage tidak hanya memberikan relaksasi secara menyeluruh, namun juga bermanfaat bagi kesehatan seperti melancarkan sirkulasi darah, menurunkan tekanan darah, menurunkan respon nyeri, dan meningkatkan kualitas tidur (Moraska et al., 2010).

Teknik dilakukan 12-15 kali pijatan permenit selama 3-10 menit. Usapan yang panjang dan lembut memberikan kesenangan dan kenyamanan bagi klien, sedangkan usapan yang pendek dan sirkuler cenderung bersifat menstimulasi (Lindquis et al., 2013). Penelitian yang dilakukan oleh Afrila (2015) mengenai teknik back massage dan akupresur terhadap penurunan tekanan darah pada penderita hipertensi hasil teknik kombinasi back massage dan akupresur efektif dalam menurunkan tekanan darah pada penderita hipertensi dengan $\mathrm{p}$ value $<\alpha$.

Mekanisme back massage yaitu meningkatkan relaksasi dengan menurunkan aktivitas saraf simpatis dan meningkatkan aktivitas saraf parasimpatis, sehingga menyebabkan terjadinya pelepasan endorfin yang membuat pembuluh darah menjadi 
vasodilatasi (Bermen et al., 2010). Berbeda dengan back massage yang merupakan teknik relaksasi dengan pijatan lembut pada jaringan, Slow deep breathing merupakan teknik relaksasi pernafasan yang dapat memberikan perenggangan kardiopulmonari sehingga stimulus perenggangan di arkus aorta dan sinus karotis diterima lalu di teruskan oleh saraf vagus ke medula oblongata sehingga mengakibatkan peningkatan refleks baroreseptor. Impuls aferen dari barireseptor mencapai pusat jantung yang akan merangsang saraf parasimpatis dan menghambat pusat simpatis, sehingga menjadi vasodilatasi sisitemik, penurunan denyut jantung, dan kontraksi jantung serta mengakibatkan perubahan tekanan darah (Sepdianto, 2008). Sejalan dengan penelitian Andri et al., (2018) yang mengatakan bahwa slow deep breathing dapat menurunkan tekanan darah sistolik dan diastolik secara bermakna pada pasien hipertensi.

Penelitian sebelumnya tentang pengaruh teknik back massage dan slow deep breathing telah dilakukan dan di ketahui hasilnya, namun belum banyak dipublikasikan jika kedua teknik relaksasi ini dilakukan secara bersamaan atau dikombinasikan, serta belum pernah dilakukan sebelumnya di Puskesmas Nabire Kota Kabupaten Nabire, maka peneliti ingin menganalisa perbandingan kombinasi teknik back massage dan slow deep breathing terhadap perubahan tekanan darah pada pasien hipertensi di Puskesmas Nabire Kota Kabupaten Nabire.

\section{METODE PENELITIAN}

\section{Desain Penelitian}

Desain penelitian yang digunakan adalah desain penelitian kuantitatif dengan metode penelitian quasy experimental dengan menggunakan pendekatan non equivalent control group pretest - posttest design untuk mengetahui pengaruh teknik gabungan Back massage dan Slow deep breathing terhadap perubahan tekanan darah pada pasien dengan hipertensi primer. Subjek penelitian berjumlah 44 responden yang menderita hipertensi yang dibagi menjadi 2 kelompok intervensi, kelompok intervensi I dan kolompok intervensi II.

\section{Participant}

Populasi responden dalam penelitian ini adalah keseluruhan pasien yang menderita hipertensi baik pasien lama atau baru yang melakukan pengobatan diunit rawat jalan Puskesmas Nabire Kota Kabupaten Nabire. Teknik pengambilan sampel dari populasi dalam penelitian ini dengan. Sampel dipilih dengan cara sederhana pada waktu penelitian sesuai dengan kriteria inklusi yang telah dikehendaki oleh peneliti. Untuk menentukan besar sampel minimal yang masih representatif berdasarkan desain penelitian yang dipilih, peneliti menggunakan dasar rumus besar sampel untuk variabel kontinyu dengan uji hipotesis beda rata-rata berpasangan. Kemudian agar menghindari adanya responden yang mengundurkan diri selama penelitian berlangsung, peneliti menambahkan $10 \%$ dari besar sampel yang didapatkan. Dari hasil penghitungan didapatkan jumlah sampel yaitu 22 responden yang dikelompokkan ke dalam kelompok intervensi I dan 22 responden ke dalam kelompok Intervensi II, sehingga jumlah seluruh sampel sebanyak 44 sampel responden.

\section{Intervention group}

Pada kelompok intervensi terapi gabungan Back massage dan Slow deep breathing diberikan selama 1 kali sehari dan dilakukan selama 5 hari, peneliti mengukur 
tekanan darah responden sebelum dilakukan intervensi pada hari pertama, data ini digunakan sebagai pretest. Kemudian dilakukan pengukuran tekanan darah responden setelah 3 hari pemberian intervensi, dan dilakukan pengukuran lagi setelah 5 hari di lakukan intervensi, data ini digunakan sebagai posttest.

\section{HASIL PENELITIAN \\ Analisis Univariat \\ Karakteristik Responden}

Tabel. 1

Distribusi Responden Berdasarkan Umur

\begin{tabular}{cccccc}
\hline Variabel & Rata-rata & SD & N & Min-Maks & $95 \%$ CI \\
\hline Umur & 48,18 & 7,206 & 44 & $39-67$ & $46,18-50,34$ \\
\hline
\end{tabular}

Berdasarkan tabel 1 hasil analisis didapatkan rata-rata umur responden kedua kelompok intervensi adalah 48,18 tahun, dengan standar deviasi 7,206. Umur termuda 39 tahun dan umur tertua 67 tahun. Dari hasil estimasi interval dapat disimpulkan bahwa $95 \%$ diyakini umur responden penelitian kedua kelompok intervensi diantara 46,18 sampai dengan 50,34 tahun.

Tabel. 2

Distribusi Responden Berdasarkan Jenis Kelamin, Riwayat Keluarga Menderita Hipertensi, Riwayat Merokok dan Terapi Standar

\begin{tabular}{|c|c|c|c|c|c|c|}
\hline \multirow[t]{2}{*}{ Variabel } & \multicolumn{2}{|c|}{$\begin{array}{c}\text { Intervensi } 1 \\
n=22\end{array}$} & \multicolumn{2}{|c|}{$\begin{array}{c}\text { Intervensi } 2 \\
n=22\end{array}$} & \multirow[t]{2}{*}{ Total } & \multirow[t]{2}{*}{$\%$} \\
\hline & $\mathrm{n}$ & $\%$ & $\mathrm{~N}$ & $\%$ & & \\
\hline \multicolumn{7}{|l|}{ Jenis Kelamin } \\
\hline Laki-laki & 8 & 36,4 & 7 & 31,8 & 15 & 34,1 \\
\hline \multirow{2}{*}{ Perempuan } & 14 & 63,6 & 15 & 68,2 & 29 & 65,9 \\
\hline & & & & & 44 & 100 \\
\hline \\
\hline & \multicolumn{6}{|c|}{ Hipertensi } \\
\hline Ya & 16 & 72,7 & 15 & 68,2 & 31 & 70,45 \\
\hline \multirow[t]{2}{*}{ Tidak } & 6 & 27,3 & 7 & 31,8 & 13 & 29,55 \\
\hline & & & & & 44 & 100 \\
\hline \multicolumn{7}{|l|}{ Riwayat Merokok } \\
\hline $\mathrm{Ya}$ & 8 & 36,4 & 7 & 31,8 & 15 & 34,1 \\
\hline \multirow[t]{2}{*}{ Tidak } & 14 & 63,6 & 15 & 68,2 & 29 & 65,9 \\
\hline & & & & & 44 & 100 \\
\hline \multicolumn{7}{|l|}{ Terapi Standar } \\
\hline Satu jenis obat & 15 & 68,2 & 11 & 50 & 26 & 59,1 \\
\hline \multirow[t]{2}{*}{ Kombinasi obat } & 7 & 31,8 & 11 & 50 & 18 & 40,9 \\
\hline & & & & & 44 & 100 \\
\hline
\end{tabular}

Berdasarkan tabel 2 hasil analisis didapatkan sebagian besar $(65,9 \%)$ responden penelitian adalah perempuan pada total kelompok intervensi 1 dan kelompok intervensi 2. Sebagian besar $(70,43 \%)$ responden penelitian memiliki riwayat keluarga menderita hipertensi pada total kelompok intervensi 1 dan kelompok intervensi 2. Sebagian besar $(65,9 \%)$ responden penelitian tidak memiliki riwayat merokok pada total kelompok intervensi 1 dan kelompok intervensi 2. Sebagian besar $(59,1 \%)$ responden penelitian mendapatkan satu jenis obat standar antihipertensi pada total kelompok intervensi 1 dan 
kelompok intervensi 2. Sedangkan yang mendapatkan dua jenis obat standar antihipertensi atau kombinasi sebanyak 40,9\% total kelompok intervensi 1 dan kelompok intervensi 2.

\section{Perubahan Rata-rata Tekanan Darah}

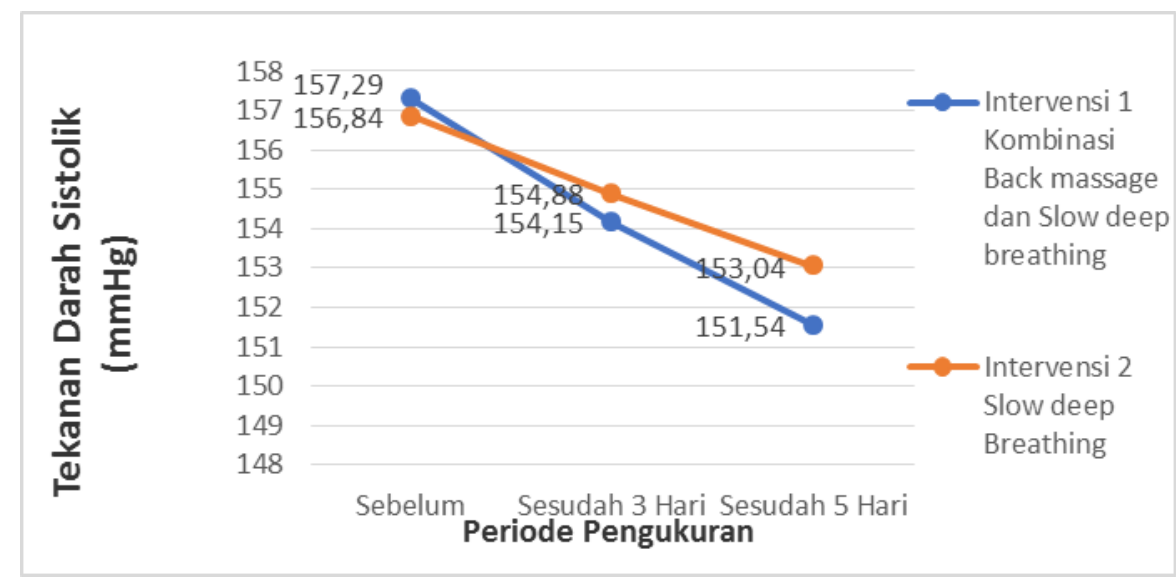

Grafik. 1

Perbandingan Rata-Rata Perubahan Tekanan Darah Sistolik menurut

Periode Pengukuran pada Kelompok Intervensi 1 dan 2

Hasil analisis menunjukkan rata-rata tekanan darah sistolik hari pertama sebelum dilakukan intervensi pada kelompok intervensi adalah $157,29 \mathrm{mmHg}$ dengan standar deviasi sebesar 8,604. Rata-rata tekanan darah sistolik pengukuran kedua setelah mendapatkan intervensi sampai ketiga yaitu pada hari ke-5 terjadi penurunan rata-rata tekanan darah sistolik menjadi 151,54 mmHg dengan standar deviasi 8,063.

\section{8}

Grafik. 2

Perbandingan Rata-Rata Perubahan Tekanan Darah Diastolik menurut Periode Pengukuran pada Kelompok Intervensi 1 dan 2

Hasil analisis didapatkan rata-rata tekanan darah diastolik pengukuran pertama pada kelompok intervensi 1 adalah 99,06 mmHg dengan standar deviasi sebesar 1,897. Pada pengukuran kedua terjadi penurunan menjadi 95,75 dengan standar deviasi 1,260. Pada pengukuran ketiga yaitu hari ke-5 terjadi penurunan lagi menjadi $96,27 \mathrm{mmHg}$ dengan standar deviasi 1,461. 


\section{Analisis Bivariat}

Tabel. 3

Hasil Uji Repeated ANOVA dengan Post Hoc Paired Wise Comparison Tekanan Darah Sistolik dan Diastolik pada Responden yang Diberikan Intervensi Kelompok 1

\begin{tabular}{|c|c|c|c|c|c|c|}
\hline \multirow{3}{*}{ Periode Pengukuran } & \multicolumn{6}{|c|}{ Variabel } \\
\hline & \multicolumn{3}{|c|}{ Sisitolik } & \multicolumn{3}{|c|}{ Diastolik } \\
\hline & $\begin{array}{l}\text { Selisih } \\
\text { Mean }\end{array}$ & IK95\% & $P$ value & $\begin{array}{l}\text { Selisih } \\
\text { Mean }\end{array}$ & IK95\% & $P$ value \\
\hline $\begin{array}{c}\text { Sebelum vs Setelah } \\
\text { Hari Ke } 3(n=22), \\
\text { mmHg }\end{array}$ & 3,136 & $\begin{array}{l}1,32- \\
4,94\end{array}$ & 0,000 & 1,318 & $\begin{array}{c}0,49- \\
2,13\end{array}$ & 0,000 \\
\hline $\begin{array}{c}\text { Sebelum vs Setelah } \\
\text { Hari } \mathrm{Ke} 5(\mathrm{n}=22) \text {, } \\
\mathrm{mmHg}\end{array}$ & 5,750 & $\begin{array}{c}3,80- \\
7,69\end{array}$ & 0,000 & 2,795 & $\begin{array}{c}1,94- \\
3,65\end{array}$ & 0,000 \\
\hline $\begin{array}{l}\text { Setelah Hari Ke } 3 \text { vs } \\
\text { Setelah Hari Ke } 5 \\
(n=22), \mathrm{mmHg}\end{array}$ & 2,614 & $\begin{array}{c}1,96- \\
3,26\end{array}$ & 0,000 & 1,477 & $\begin{array}{c}0,82- \\
2,12\end{array}$ & 0,000 \\
\hline
\end{tabular}

Uji pairwise comparison (Bonferroni)

Berdasarkan tabel 3 diperoleh nilai $\mathrm{p}=0,000$ untuk perbandingan semua kelompok tekanan darah sistolik. Selisih antar pengukuran sebelum hingga 5 hari sesudah diberikan terapi yaitu $5,75 \mathrm{mmHg}$. Sehingga dapat ditarik kesimpulan a) secara statistik dan klinis, tekanan darah sistolik sebelum diberikan intervensi kombinasi tehnik Back massage dan slow deep breathing berbeda dengan tekanan darah sistolik sesudah diberikan terapi 3 hari; b) secara statistik dan klinis, tekanan darah sistolik sebelum diberikan intervensi kombinasi tehnik Back massage dan slow deep breathing berbeda dengan tekanan darah sistolik sesudah diberikan terapi 5 hari; c) secara statistik dan klinis, tekanan darah sistolik sesudah 3 hari diberikan intervensi kombinasi tehnik Back massage dan slow deep breathing berbeda dengan tekanan darah sistolik sesudah diberikan terapi selama 5 hari.

Kemudian untuk perbandingan semua kelompok tekanan darah diastolik dengan Uji pairwise comparison, diperoleh nilai $\mathrm{p}=0,000$ untuk tekanan darah diastolik sebelum diberikan terapi Back massage dan slow deep breathing, nilai $\mathrm{p}=0,000$ untuk tekanan darah diastolik sesudah 3 hari diberikan terapi Back massage dan slow deep breathing dan nilai $\mathrm{p}=0,000$ untuk tekanan darah diastolik sesudah 5 hari diberikan terapi Back massage dan slow deep breathing. Selisih antar pengukuran sebelum hingga 5 hari sesudah diberikan terapi yaitu $2,79 \mathrm{mmHg}$. Sehingga dapat di tarik kesimpulan a) secara statistik dan klinis, tekanan darah diastolik sebelum diberikan intervensi Back massage dan slow deep breathing berbeda dengan tekanan darah diastolik sesudah diberikan terapi 3 hari; b) secara statistik dan klinis, tekanan darah diastolik sebelum diberikan intervensi Back massage dan slow deep breathing berbeda dengan tekanan darah diastolik sesudah diberikan terapi 5 hari; c) secara statistik dan klinis, tekanan darah diastolik sesudah 3 hari diberikan intervensi back massage dan slow deep breathing berbeda dengan tekanan darah diastolik sesudah diberikan terapi 5 hari. 
Tabel. 4

Hasil Uji Repeated ANOVA dengan Post Hoc Paired Comparison Tekanan Darah Sistolik dan Diastolik pada Responden yang Diberikan Intervensi Kelompok 2

\begin{tabular}{ccccccc}
\hline & \multicolumn{5}{c}{ Variabel } \\
\cline { 2 - 7 } Periode Pengukuran & \multicolumn{3}{c}{ Sisitolik } & \multicolumn{3}{c}{ Diastolik } \\
\cline { 2 - 7 } & $\begin{array}{c}\text { Selisih } \\
\text { Mean }\end{array}$ & IK95\% & P value & $\begin{array}{c}\text { Selisih } \\
\text { Mean }\end{array}$ & IK95\% & P value \\
\hline $\begin{array}{c}\text { Sebelum vs Setelah Hari } \\
\text { Ke 3 (n=22), mmHg }\end{array}$ & 1,955 & $\begin{array}{c}1,02- \\
2,88\end{array}$ & 0,000 & $-0,159$ & $\begin{array}{c}-1,02- \\
0,70\end{array}$ & 1,000 \\
\hline $\begin{array}{c}\text { Sebelum vs Setelah Hari } \\
\text { Ke 5 (n=22), mmHg }\end{array}$ & 3,795 & $\begin{array}{c}2,59- \\
4,99\end{array}$ & 0,000 & 1,386 & $\begin{array}{c}0,30- \\
2,46\end{array}$ & 0,006 \\
\hline $\begin{array}{c}\text { Setelah Hari Ke 3 vs } \\
\text { Setelah Hari Ke 5 } \\
\text { (n=22), mmHg }\end{array}$ & 1,841 & $\begin{array}{c}1,21- \\
2,47\end{array}$ & 0,000 & 1,545 & $\begin{array}{c}0,84- \\
2,25\end{array}$ & 0,000 \\
\hline
\end{tabular}

Uji pairwise comparison (Bonferroni)

Berdasarkan tabel 4 di diperoleh nilai $\mathrm{p}=0,000$ untuk tekanan darah sistolik sebelum diberikan terapi slow deep breathing, nilai $\mathrm{p}=0,000$ untuk tekanan darah sistolik sesudah 3 hari diberikan terapi dan nilai $\mathrm{p}=0,000$ untuk tekanan darah sistolik sesudah 5 hari di berikan terapi. Selisih antar pengukuran sebelum hingga 5 hari sesudah diberikan terapi yaitu 3,8 $\mathrm{mmHg}$. Sehingga dapat ditarik kesimpulan a) secara statistik dan klinis, tekanan darah sistolik sebelum diberikan intervensi slow deep breathing berbeda dengan tekanan darah sistolik sesudah diberikan terapi 3 hari; b) secara statistik dan klinis, tekanan darah sistolik sebelum diberikan intervensi slow deep breathing berbeda dengan tekanan darah sistolik sesudah diberikan terapi 5 hari; c) secara statistik dan klinis, tekanan darah sistolik sesudah 3 hari diberikan intervensi slow deep breathing berbeda dengan tekanan darah sistolik sesudah diberikan terapi 5 hari.

Pada tekanan darah diastolik dengan uji pairwise comparison diperoleh nilai $\mathrm{p}=1,000 ; \mathrm{p}=0,006$; dan $\mathrm{p}=0,000$ untuk perbandingan semua kelompok didapatkan selisih antar pengukuran sebelum hingga 5 hari sesudah diberikan terapi yaitu 1,39 mmHg. Sehingga perbandingan semua kelompok tekanan darah diastolik dapat di tarik kesimpulan a) secara statistik dan klinis, tekanan darah diastolik sebelum diberikan intervensi slow deep breathing berbeda dengan tekanan darah diastolik sesudah diberikan terapi 3 hari mengalami peningkatan $0,16 \mathrm{mmHg}$; b) secara statistik dan klinis, tekanan darah diastolik sebelum diberikan intervensi slow deep breathing berbeda dengan tekanan darah diastolik sesudah diberikan terapi 5 hari; c) secara statistik dan klinis, tekanan darah diastolik sesudah 3 hari diberikan intervensi slow deep breathing berbeda dengan tekanan darah diastolik sesudah diberikan terapi 5 hari.

\section{PEMBAHASAN}

\section{Karakteristik Responden}

Pasien hipertensi yang menjadi responden penelitian baik pada kelompok intervensi 1 dan kelompok intervensi 2 di Puskesmas Nabire Kota Kabupaten Nabire mempunyai umur antara 39 tahun sampai dengan 67 tahun. Dari hasil penelitian ini usia responden masuk dalam kategori usia pertengahan (middle age). Penelitian ini juga sesuai dengan penelitian yang dilakukan oleh Moeini (2011) pada 19.661 orang dewasa dengan usia > 18 tahun didapatkan hasil sebagian besar subyek yang mengalami hipertensi $(74 \%)$ berusia $\geq 50$ tahun. Penelitian ini sesuai dengan pendapat dari Lewis 
(2007) bahwa hipertensi dimulai pada usia 30 - 50 tahun. Perubahan fungsi endotel pembuluh darah berkontribusi terhadap proses terjadinya aterosklerosis dan hipertensi.

Responden penelitian baik pada kelompok intervensi 1 maupun kelompok intervensi 2, sebagian besar $(65,9 \%)$ berjenis kelamin perempuan. Hasil penelitian ini berbeda dengan penelitian Jarky et al., (2005) pada 860 responden usia 21-70 tahun didapatkan prevalensi hipertensi pada laki-laki sedikit lebih banyak $(6,4 \%)$ dibandingkan dengan perempuan $(6,1 \%)$. Penelitian Schein (2001) juga berbeda dengan hasil penelitian, dimana dari 131 responden yang berusia 50-60 tahun lebih banyak lakilaki yang mengalami hipertensi dibandingkan dengan perempuan. Orshal \& Kahlil (2004) menyatakan bahwa insiden hipertensi pada laki-laki dan perempuan post menopause lebih tinggi dibandingkan dengan wanita premenopause. Perbedaan jenis kelamin ini berkaitan dengan perbedaan tonus pembuluh darah dan kemungkinan efek proteksi dari hormon seks wanita yaitu estrogen dan progesteron.

Responden penelitian baik pada kelompok intervensi maupun kelompok kontrol sebagian besar $(70,45 \%)$ mempunyai riwayat keluarga menderita hipertensi. Hasil penelitian ini sesuai dengan yang dilakukan oleh Wang et al., (2008) tentang perubahan tekanan darah dan risiko hipertensi berhubungan dengan orang tua menderita hipertensi. Nash (2003) menambahkan bahwa hipertensi juga berhubungan dengan abnormalitas sistem saraf simpatis yang diwariskan. Sistem saraf simpatis adalah bagian dari sistem saraf otonom yang berfungsi untuk mengontrol denyut jantung, tekanan darah dan diameter pembuluh darah.

Responden penelitian baik pada kelompok intervensi 1 maupun kelompok intervensi 2 sebagian besar $(65,9 \%)$ tidak mempunyai riwayat merokok. Pada penelitian ini juga ditemukan sebagian kecil $(34,1 \%)$ responden mempunyai riwayat merokok. Penelitian dari Gropelli et al., (1992) pada 10 orang perokok normotensi didapatkan hasil perokok mempunyai tekanan darah yang lebih tinggi dan variabilitas tekanan darah yang meningkat. Merokok dapat menjadi faktor risiko terjadinya penyakit kardiovaskuler. Merokok sudah diketahui sebagai faktor resiko penyakit kardiovaskuler termasuk hipertensi dan penyakit jantung iskemik. Di dalam rokok terdapat beberapa bahan kimia termasuk nikotin, tar dan komponen gas termasuk karbon monoksida (CO). Nikotin mempunyai efek akut dan kronik dalam meningkatkan aktivitas simpatis. Mekanisme utama karbon monoksida sebagai penyebab penyakit kardiovaskuler akibat dari efek hipoksia. Karbon monoksida juga berkontribusi terhadap terjadinya aterosklerosis akibat kerusakan endotel pembuluh darah (Zevin et al., 2011).

Responden penelitian baik pada kelompok intervensi 1 maupun kelompok intervensi 2 sebagian besar $(59,1 \%)$ mendapatkan satu jenis obat standar antihipertensi. Pemberian satu jenis obat antihipertensi (monoterapi) pada responden sudah sesuai dengan pedoman managemen hipertensi yang direkomendasikan oleh JNC 7 (The

Seventh Report of the Joint National Committee on Detection, Evaluation and Treatment of High Blood Pressure). Terapi anti hipertensi diawali dengan modifikasi gaya hidup pada pasien pre hipertensi dan dimulai dengan pengobatan antihipertensi bila tekanan darahnya $>140 / 90 \mathrm{mmHg}$ (Chobanian et al., 2013).

\section{Pengaruh Kombinasi Back Massage dan Slow Deep Breathing terhadap Tekanan Darah}

Rata-rata tekanan darah sistolik dan diastolik setelah latihan back massage dan slow deep breathing berbeda secara signifikan antara kelompok yang melakukan latihan back massage dan Slow deep breathing dengan kelompok yang hanya melakukan 
latihan slow deep breathing $(\alpha<0,05)$. Hasil penelitian ini sesuai dengan hipotesis penelitian yaitu rata-rata tekanan darah setelah melakukan back massage dan slow deep breathing berbeda antara kelompok yang melakukan kombinasi back massage dan Slow deep breathing dengan kelompok yang hanya melakukan slow deep breathing. Dari hasil penelitian ini dapat diketahui bahwa latihan back massage dan Slow deep breathing pada pasien hipertensi dapat menurunkan tekanan darah sistolik $5,75 \mathrm{mmHg}$ dan tekanan darah diastolik $2,79 \mathrm{mmHg}$, sedangkan yang hanya melakukan slow deep breathing pada pasien hipertensi dapat menurunkan tekanan darah sistolik 3,8 $\mathrm{mmHg}$ dan tekanan darah diastolik $1,39 \mathrm{mmHg}$.

Intervensi ini berpengaruh dikarenakan back massage (pijat punggung) dapat meningkatkan relaksasi dengan menurunkan aktivitas saraf simpatis dan meningkatkan aktivitas saraf parasimpatis sehingga terjadi vasodilatasi diameter arteriol (Orshal, 2004). Sistem saraf parasimpatis melepaskan neurotransmiter asetilkolin untuk menghambat aktifitas saraf simpatis dengan menurunkan kontraktilitas otot jantung, volume sekuncup, vasodilatasi arteriol dan vena kemudian menurunkan tekanan darah (Muttaqin, 2009).

Hasil penelitian oleh Mohebbi et al., (2014) menunjukkan bahwa setelah intervensi back massage, terjadi penurunan tekanan darah sistolik dan diastolik masing-masing $6.44 \mathrm{mmHg}$ dan $4.77 \mathrm{mmHg}(\mathrm{p}=0.001)$ pada kelompok intervensi dan 2,31 dan 1,51 $\mathrm{mmHg}$ pada kelompok kontrol $(\mathrm{p}=0.001)$. Slow deep breathing salah satu intervensi dalam penelitian ini yang bertujuan meningkatkan aktivitas vagal dan karena itu menurunkan dasar denyut jantung dan tekanan darah.

Hasil penelitian ini sesuai dengan penelitian Battegay et al., (2005) yang dilakukan pada 20 responden dengan hipertensi (usia 56,4 $\pm 1,9$ tahun) dan 26 kontrol (usia $52 \pm$ 1,4 tahun) dengan kedua kelompok melakukan intervensi dengan bernafas normal dan kontrol pernafasan lambat (6x/menit) dan cepat (15x/menit). Tekanan darah dan interval pernafasan diukur dalam posisi duduk selama melakukan intervensi. Sensitivitas barorefleks diukur dengan autoregressive spectral analysis dan alpha angle. Dari hasil penelitian pernafasan lambat (slow breathing) dapat menurunkan tekanan darah sistolik dan diastolik pada pasien hipertensi (dari 147,7 $\pm 3,7 \mathrm{mmHg}$ menjadi $141 \pm 4 \mathrm{mmHg}$, $\mathrm{p}<0,05$ dan dari $82,7 \pm 3 \mathrm{mmHg}$ menjadi $77,8 \pm 3,7 \mathrm{mmHg}, \mathrm{p}<0,01)$. Pada pernafasan lambat juga meningkatkan sensitivitas barorefleks pada pasien hipertensi (dari 5,5 $\pm 3,7$ $\mathrm{ms} / \mathrm{mmHg}$ menjadi $10,3 \pm 2,0 \mathrm{~ms} / \mathrm{mmHg}$ ).

Hasil penelitian ini juga sejalan dengan penelitian Grosman et al., (2001) tentang kontrol nafas dalam menurunkan tekanan darah. Penelitian ini dilakukan pada 33 pasien hipertensi yang dibagi menjadi dua kelompok, yaitu 18 pasien melakukan nafas lambat dengan dibantu musik interaktif yang mampu menurunkan frekuensi nafas dan 15 pasien kontrol dengan walkman. Intervensi dilakukan selama 10 menit selama 8 minggu. Dari hasil penelitian menunjukkan nafas lambat dengan panduan musik dapat menurunkan tekanan darah sistolik 7,5 $\mathrm{mmHg}$ dan tekanan darah diastolik $4 \mathrm{mmHg}$.

Penelitian lain yang mendukung adalah penelitian randomized double-blind controlled study oleh Grossman et al., (2001) yang dilakukan pada 61 orang hipertensi, 32 pasien melakukan nafas lambat selama 10 menit/hari dalam waktu 8 minggu dengan bantuan musik yang mampu menurunkan frekuensi nafas dan 29 pasien hanya menggunakan walkman. Hasil penelitian menunjukkan nafas lambat dapat menurunkan tekanan darah sistolik 15,2 $\mathrm{mmHg}$ dan tekanan darah diastolik $10 \mathrm{mmHg}$. Slow deep breathing berpengaruh pada modulasi sistem kardiovaskuler. Slow deep breathing mempunyai efek meningkatkan fluktuasi dari interval RR (rate of respiration). Fluktuasi 
peningkatan interval RR (relatif terhadap perubahan tekanan darah) berdampak pada peningkatan efektifitas barorefleks dan dapat berkontribusi terhadap penurunan tekanan darah. Slow deep breathing juga menurunkan aktivitas simpatis dengan meningkatkan central inhibitory rhythms yang akhirnya berdampak pada penurunan tekanan darah ketika barorefleks diaktivasi. Slow deep breathing juga berpengaruh terhadap peningkatan volume tidal sehingga mengaktifkan Hering-Breuer reflex yang berdampak pada penurunan aktivitas kemorefleks dan akhirnya meningkatkan sensitivitas barorefleks. Mekanisme ini dapat menurunkan aktivitas simpatis dan tekanan darah (Battegay et al., 2005).

Latihan nafas lambat dapat meningkatkan tonus parasimpatis, menurunkan aktivitas simpatis, meningkatkan fungsi kardiovaskuler dan pernafasan serta menurunkan efek stress. Pinheiro et al., (2007) memperkuat hasil penelitian ini dengan hasil penelitiannya bahwa teknik slow breathing dapat meningkatkan sistem modulasi kardiorespirasi pada pasien hipertensi dengan meningkatkan barorefleks, variabilitas denyut jantung dan menurunkan tekanan darah. Slow breathing dapat digunakan sebagai terapi tambahan pada penyakit kardiovaskuler. Pernyataan ini dikuatkan oleh Anderson et al., (2010) yang menyebutkan bahwa teknik SDB akan menghasilkan sinyal yang mengaktifkan reflek baroreseptor melalui peningkatan tekanan darah arteri di pembuluh darah karena peningkatan volume stroke dan bulk heart di jantung kiri. Sebagai akibatnya akan ada penurunan tekanan darah dari aktivasi reflek baroreseptor yang mengirimkan sinyal ke pusat kardiovaskular (Anderson, 2015; Andri et al., 2018).

Berdasarkan hasil penelitian dan berbagai penelitian dan teori yang terkait, peneliti berasumsi bahwa latihan back massage dan slow deep breathing dapat digunakan sebagai terapi nonfarmakologi pada pasien hipertensi, baik dalam bentuk terapi mandiri atau terapi tambahan bersama obat antihipertensi. Latihan back massage dan slow deep breathing mudah untuk dilakukan di rumah dan tidak mempunyai efek samping serta menurunkan biaya pengobatan bagi pasien hipertensi. Dengan pemberian terapi nonfarmakologis berupa kombinasi gabungan terapi BM dan SDB memberikan dampak yang sama yaitu mengstimulasi respons saraf otonom melalui pengeluaran neurotransmitter endorphin yang berefek pada penurunan respon saraf simpatis dan peningkatan respon parasimpatis. Stimulasi saraf simpatis meningkatkan aktivitas tubuh, sedangkan respons parasimpatis lebih banyak menurunkan aktivitas tubuh atau relaksasi sehingga dapat menurunkan aktivitas metabolik yang berdampak pada fungsi jantung, tekanan darah dan pernafasan. Kondisi ini akan meningkatkan adaptasi fisiologis dan rasa nyaman pada individu.

\section{SIMPULAN}

Ada perbedaan penurunan yang signifikan rata-rata tekanan darah sistolik setelah latihan Back massage dan slow deep breathing antara kedua kelompok. Ada perbedaan penurunan yang signifikan rata-rata tekanan darah diastolik setelah latihan slow deep breathing antara kedua kelompok.

Intervensi terapi back massage dan slow deep breathing diimplementasikan dalam penelitian ini, mengeksplorasi dampak pada perubahan tekanan darah pasien hipertensi. Peneliti menyimpulkan bahwa intervensi latihan back massage dan slow deep breathing secara klinis berkhasiat, yang dapat menurunkan tekanan darah. Ini memerlukan peran perawat medikal bedah dalam membantu pasien hipertensi untuk menurunkan tekanan darah. Sementara itu, peneliti menganggap intervensi ini sebagai pendekatan baru khususnya perawat medikal bedah untuk menyediakan perawatan holistik pada pasien 
hipertensi . Namun, intervensi latihan back massage dan slow deep breathing pada hasil tekanan darah masih terlihat tinggi, faktor lain juga harus diperhatikan dan perlu dieksplorasi lebih lanjut. Kompetensi perawat terhadap Back massage dan slow deep breathing perlu dikembangkan dan dievaluasi sebelum peneliti menerapkan intervensi ini lebih luas.

\section{SARAN}

Bagi pelayanan kesehatan di harapkan mampu meningkatkan kemampuan perawat dalam melakukan latihan back massage dan Slow deep breathing sebagai salah satu intervensi keperawatan dalam memberikan asuhan keperawatan pada pasien hipertensi melalui diseminasi dan pelatihan dan meningkatkan kemandirian pasien hipertensi dalam melakukan latihan back massage dan slow deep breathing melalui pendidikan kesehatan yang terprogram dengan dilengkapi leaflet tentang hipertensi, latihan slow deep breathing serta pedoman nutrisi pada pasien hipertensi.

Bagi pendidikan keperawatan diharapkan emfasilitasi mahasiswa keperawatan untuk meningkatkan pemahaman dan mengembangkan manajemen non farmakologi khususnya latihan back massage dan slow deep breathing dengan mengadakan seminar ilmiah.

Bagi Penelitian Berikutnya perlu diteliti lebih lanjut tentang latihan back massage dan slow deep breathing untuk menurunkan tekanan darah pada pasien hipertensi dengan mempertimbangkan asupan total natrium setiap hari, perubahan frekuensi pernafasan dan nadi, variasi usia yang lebih lebar, jumlah responden yang lebih besar, waktu latihan yang lebih lama dan kondisi pasien yang lebih kompleks seperti pasien hipertensi dengan komplikasi. Penelitian yang sudah dilakukan sudah sesuai dengan proposal yang telah dibuat tetapi masih ada beberapa keterbatasan baik dalam pelaksanaan pengumpulan data. Pelaksanaan pengumpulan data tidak dilakukan pada jam yang sama untuk setiap responden baik kelompok intervensi 1 dan kelompok intervensi 2. Peneliti mengatasi masalah tersebut untuk meminimalkan pengaruh variasi diurnal tekanan darah dengan melakukan pengukuran tekanan darah hanya pada pagi hari antara pukul 07.00 sampai dengan pukul 10.00. Pengontrolan dalam mengkonsumsi obat antihipertensi responden baik kelompok intervensi 1 dan kelompok intervensi 2 menjadi keterbatasan peneliti karena peneliti tidak dapat mengontrol konsumsi obat responden mulai dari tipe obat, kepatuhan minum obat, waktu minum obat, dan berapa lama responden telah mengkonsumsi obat anti hipertensi.

\section{DAFTAR PUSTAKA}

Afrila, D. E. (2015). Efektifitas Kombinasi Terapi Slow Stroke Back Massage dan Akupresur terhadap Penurunan Tekanan Darah pada Penderita Hipertensi. JOM, 2(2)

Anderson, D. E., McNeely, J. D., \& Windham, B. G. (2010). Regular Slow-Breathing Exercise Effects on Blood Pressure and Breathing Patterns at Rest. Journal of Human Hypertension, 24(12), 807-813. https://doi.org/10.1038/jhh.2010.18

Anderson, E. (2015). Effect of Slow Deep Breathing to Blood Pressure and Heart Rate Hypertensive Patients at Adventist Hospital in Bandar Lampung, Indonesia

Andri, J., Waluyo, A., Jumaiyah, W., \& Nastashia, D. (2018). Efektivitas Isometric Handgrip Exercise dan Slow Deep Breathing Exercise terhadap Perubahan Tekanan Darah pada Penderita Hipertensi. Jurnal Keperawatan Silampari, 2(1), 371-384. doi:10.31539/jks.v2i1.382 
Battegay, E. J., Gregory, Y. H., \& George L. B. (2005). Hypertension Principles and Practice, USA: Taylor \& Francis Group

Bisht, R., Katiyar. A., Singh, R., \& Mittal, P. (2009). Antibiotic Resistance-A Global Issue of Concern. Asian Journal of Pharmaceutical and Clinical Research, 2(2), 189

Carlson, W. (2016). Mengatasi Hipertensi. Vols. pp:13-48. Bandung: Nuansa. Cendekia

Chobanian, A. V., Bakris, G. L., \& Black, H. R. (2013). The Sevent Report of the Joint Nation Committee on Prevention, Detection, Evaluation, and Treatment of High Blood Pressure, http:jama.ama-assn.org/cgi/reprint/289.19.2560vl

Groppelli, A., Giorgi, D. M. A., Omboni, S., \& Parati, G. (1992). Persisten Blood Pressure Increase Induced by Heavy Smoking. Journal of Hypertension, 10(5), 495. DOI: $10.1097 / 00004872-199205000-00014$

Grossman, E., Grossman, A., Schein, M. H., Zimlichman, R., \& Gavish, B. (2001). Breathing-Control Lower Blood Pressure. http:www.nature.com/jhh/journal/ v15/n4/pdf/1001147a.pdf

IFPMA. (2016). Hypertension: Putting the Pressure on the Silent Killer. Retrieved Maret 18, 2018 From Https://Www.Ifpma.Org/Resource-Centre/HypertensionPutting-The-Pressure-On-The-Silent-Killer/. Published on: 17 May 2016

Irawan, O. (2017). Pengaruh Terapi Rendam Air Hangat pada Kaki Sambil Mendengarkan Musik Klasik terhadap Penurunan Tekanan Darah pada Penderita Hipertensi di Wilayah Kerja Puskesmas Basuki Rahmad Kota Bengkulu. Poltekkes Kemenkes BKL

Jarky, F., Awadhi. N., Fadli, H., Tawfic, A. S., Sebai, A. R., \& Mousawi, M. (2005). Prevalence of Hypertension in Young and Middle Aged Kuwaiti Citizens in Primary Health Care. Kuwait Medical Journal, 37(2), 116-119

Kozier, E. B., \& Snyder, S. (2010). Buku Ajar Fundamental Keperawatan : Konsep, Proses \& Praktek (7 ed., Vol I). Jakarta: EGC

Lewis, P. (2007). Medical Surgical Nursing Assesment and Management of Clinical Problems. Seventh Edition. Mosby Elsevier

Lindquist, L., Snyder, S., \& Tracy, T. (2013). Complementary \& Alternative Therapies in Nursing: Seventh Edition Ruth, Limited Preview

Majid, A. (2017). Asuhan Keperawatan pada Pasien dengan Gangguan Sistem Kardiovaskuler. Yogyakarta: Pustaka Baru Press

Moeini, M. (2011). The Effect of Massage Therapy on Blood Pressure of Women with Pre-Hypertension. Theses. University of Medical Sciences

Mohebbi, Z., Moghadasi, M., Homayouni, K., \& Nikou, M. H. (2014). The Effect of Back Massage on Blood Pressure in the Patients with Primary Hypertension in 2012-2013: A Randomized Clinical Trial. Int J Community Based Nurs Midwifery, 2(4), 251-258. http:// ijcbnm.sums.ac.ir

Moraska, A., Pollini, R. A., Boulanger, K., Brooks, M. Z., \& Teitlebaum, L. (2010). Physiological Adjustments to Stress Measures Following Massage Therapy: a Review of the Literature. Evid Based Complement Alternat Med, 7(4), 409-418

Muttaqin, M. (2009). Asuhan Keperawatan Klien dengan Gangguan Sistem. Kardiovaskular dan Hematologi. Jakarta: Salemba Medika

Nash, N. (2003). Blood Lead, Blood Pressure, and Hypertension in Perimenopausal and Postmenopausal Women. http://jama.ama-assn.org/cgi/content/full/289/12/1523 
Orshal, J., M., \& Khalil, R. A. (2004). Gender, Sex Hormones, and Vascular Tone. Am J Physiol Regul Integr Comp Physiol, 286(2), R2349. DOI: 10.1152/ajpregu.00338.2003

Pinheiro, C. H. J., Medeiros, R. A. R., Pinheiro, D. G. M., \& Marinho, M. J. F. (2006). Spontaneous Respiratory Modulation Improves Cardiovascular Control in Essential Hypertension. Arquivos Brasileiros de Cardiologia, 88(6), 651-9. http:www.scielo.br/pdfabc/v88 n6/en_v88n6a05.pdf

Sartika, A., Wardi, A., \& Sofiani, Y. (2018). Perbedaan Efektivitas Progressive Muscle Relaxation (PMR) dengan Slow Deep Breathing Exercise (SDBE) terhadap Tekanan Darah Penderita Hipertensi. Jurnal Keperawatan Silampari, 2(1), 356370. https://doi.org/https://doi.org/10.31539/jks.v2i1.380

Schein, S. (2001). Treating Hypertension with a Device that Slow and Regularises Breathing : A Randomised, Double-Blind Controlled Study. http:www.nature. com/jhh/journal/v15/n4/pdf/1001148a.pdf

Sepdianto, T. C. (2008). Pengaruh Latihan Slow Deep Breathing terhadap Penurunan Tekanan Darah pada Pasien Hipertensi di Kota Blitar. Program Pasca Sarjana FIK-UI. Tesis. Tidak dipublikasikan

Wang, N. Y., Young, J. H., Meoni, L. A., Ford, D. E., Erlinger, T. P., \& Klag, M. J. (2008). Blood Pressure Change and Risk of Hypertension Associated with Parental Hypertension. Arch Intern Med, 168(6), 643-8. DOI: 10.1001/archinte.168.6.643

World Health Organization (WHO). (2013). A global Brief on Hypertension: Silent Killer. Global Public Health Crisis

Zevin, S., Saunders, S., Gourlay, S. G., Jacob, P., \& Benowitz, N. L. (2011). Cardiovascular Effect of Carbon Monoxide and Cigarette Smoking. J Am Coll Cardiol, 38(6), 1633-8. DOI: 10.1016/s0735-1097(01)01616-3 